\title{
DISCURSO PROFERIDO NO DIA 18 DE \\ FEVEREIRO DE 2019, POR OCASIÃO DO \\ RECEBIMENTO DO TROFÉU AGERSON TABOSA
}

\author{
Raimundo Bezerra Falcão \\ Livre-Docente em Filosofia do Direito \\ Mestre em Direito Público \\ Presidente de Honra da Academia Cearense de Direito - \\ ACED \\ Membro Efetivo do Instituto dos Advogados Brasileiros \\ com sede no Rio de Janeiro \\ Membro Efetivo do Instituto Brasileiro de Direito \\ Constitucional com sede em São Paulo \\ Membro da Academia de Ciências Sociais do Ceará \\ Membro da Academia Cearense de Retórica \\ Membro do Instituto dos Advogados Cearenses - IAC \\ Professor Titular Aposentado da Graduação e Pós- \\ Graduação da Universidade Federal do Ceará - UFC, tendo \\ lecionado Filosofia do Direito (graduação), Hermenêutica e \\ Direito Econômico na pós-graduação
}

Nos caminho da vida, são muitos os desvios e encruzilhadas que podem distorcer o norte ou confundir o destino do caminhante, ainda quando este não seja desavisado. São curvas aqui, cancelas ali, veredas acolá. E não adianta àquele supor-se iluminado. As obscuridades e desvãos da caminhada são sempre mais aptos a enegrecer e ofuscar a visão do viandante.

Como, então, safar-se o viageiro a tamanhas ciladas? Atentando para o luzeiro que determinados faróis humanos aprestam-se a fazer reluzir. Apoiando-se no cajado que certos guias dispõem-se a estender-lhe.

Que luminares são esses? Que condutores são tais?

Os professores e os mestres. Aqueles que ministram preceitos ou instruções a quem se ache sedento de recebê-los.

Nem todo professor é, ao mesmo tempo, um mestre. E não o é porque nem sempre ensina para a vida e para a alma. Transmite lições aos que ouvem, mas sem o dom de incutir-lhes na alma o alimento capaz de matar-lhes a fome de paz, e de dessedentá-los do anseio de felicidade. Leva-os a aprender, porém não os faz apreender. Pode até ensinar muitas coisas belas e úteis. Entretanto, não os leva a aperceberem-se do mais relevante: o amor ao irmão. E ensinando-lhes a amar o irmão, e, assim, ensinando-lhes igualmente a amar a Deus. Não se lhe negam os méritos. Mas não os tem por inteiro.

Diferentemente age o mestre. Este não é somente professor. É-o, tem-se como certo. Mas também, e sobretudo, é mestre. E seus ouvintes não são apenas alunos. São, principalmente, discípulos e seguidores. Gozam, fartamente, do pão da sabedoria, este que sacia a alma e lhe dá forças para a busca constante da verdadeira vida. A vida em paz e com felicidade.

Isso não apaga ou esmaece a grandeza e nobreza do processor. Todavia, assinala, para além disso, a fecundidade do mestre. E alteia, à inatingibilidade, as alvíssaras que se hão de conferir ao professor-mestre. 
Agerson Tabosa Pinto foi autenticamente mestre, sem, no entanto, esquecer de revelar-se professor. Trazia a seus discípulos, é verdade, o compassado avançar das legiões dos Césares, mas enfatizava, de permeio a isso, o papel civilizatório dos conquistadores romanos, tangido notadamente pela monumental e sólida arquitetura do Direito Romano. Fazia-os compreender que a cultura jurídica não seria tão profunda no Ocidente se não fora o jusromanismo, com seus instintos que ainda hoje florescem na Europa e nas Américas, especialmente.

Os passos rápidos e curtos do professor-mestre Agerson Tabosa Pinto conduziram-no a bem longe. Não ocupou somente a cátedra universitária. Foi também administrador público, na condição de operoso Diretor da Faculdade de Direito da Universidade Federal do Ceará. Integrou, ademais, o Ministério Público do Ceará. E teve tempo ainda de deixar trabalhos publicados.

O recebimento do Troféu Agerson Tabosa é, para mim, uma sublime honraria. Sei que meus méritos não bastam para tanto. Há, com certeza, em meio a isso tudo, a atenciosa interferência da professora-mestra Maria Vital da Rocha, Doutora em Direito, civilista, romanista e jurista de nomeada.

Sou-lhe, pela deferência, perenemente grato. Auguro-lhe, sempre e sempre, cada vez mais êxitos em suas inúmeras tarefas acadêmicas e intelectuais em geral.

Disse-o. 